\title{
The association of hepatitis c virus infection status with serum glucose levels
}

\author{
Yinping $\mathrm{Li}^{1,2+}$, Xiaomei Wang ${ }^{1,3+}$, Ge Yu ${ }^{1}$, Haibo Sun ${ }^{1}$, Juan $\mathrm{Lv}^{1}$, Xiumei Chi ${ }^{1,3}$, Ruihong Wu ${ }^{1,3}$, Xiuzhu Gao ${ }^{1,3}$
} and Junqi $\mathrm{Niu}^{1,3^{*}}$

\begin{abstract}
Background: Hepatitis C virus ( $\mathrm{HCV}$ ) infection is commonly associated with a disturbance of glucose metabolism. However, there have been conflicting reports on whether the clearance of the HCV may be followed by changes of serum blood glucose and insulin resistance. The aim of the present study was to evaluate the impact of HCV and antiviral treatment on serum glucose levels and other glucose metabolism parameters.

Methods: A retrospective analysis of $306 \mathrm{HCV}$-infected patients was performed. Fasting serum blood glucose (FBG) levels in these patients were compared with that of 325 healthy individuals. Serum parameters of glucose metabolism were measured in 183 patients with chronic hepatitis $\mathrm{C}$ at baseline, at the end of interferon a-2b plus ribavirin treatment, and at 24 weeks post-treatment.

Results: Patients with HCV infection had significantly higher FBG level than healthy controls $(5.57 \pm 0.74$ vs. $5.11 \pm$ $0.83 \mathrm{mmol} / \mathrm{l}, P<0.001$ ). After antiviral treatment, we found a significant reduction in FBG levels regardless of the outcome of treatment. However, after stopping treatment the serum FBG levels were significantly elevated in the sustained virological response (SVR) and non-responder groups, and maintained high level until week 24 posttreatment. In both groups, the levels of serum FBG after 24 weeks post-treatment were still lower than pretreatment levels. In sustained responders, fasting insulin $(P=0.007)$, C-peptide $(P<0.001)$ and HOMA-IR $(P<0.001)$ significantly decreased, and the insulin sensitivity index $(I S I)$ increased $(P<0.001)$ at the end of the treatment comparing with pre-treatment levels, while no significant difference was observed in non-responder group. HOMA$\beta$ values were increased in both groups at the end of treatment (both $P<0.001$ ).
\end{abstract}

Conclusion: The total serum FBG level in HCV infected patients was higher than that in healthy controls. Clearance of HCV was associated with reduced glucose and improved insulin resistance.

Keywords: Chronic hepatitis C, Antiviral treatment, Fasting blood glucose, Sustained virological response

\section{Background}

Hepatitis $\mathrm{C}$ virus (HCV) infects over 170 million individuals worldwide, and is an important cause of liver cirrhosis and hepatocellular carcinoma [1]. Currently, the therapy agents mainly consist of direct-acting agents such as protease, polymerase, and polymerase accessory protein inhibitors, while the interferon (IFN) and

\footnotetext{
* Correspondence: junqi_niu@163.com

${ }^{\dagger}$ Yinping Li and Xiaomei Wang contributed equally to this work.

${ }^{1}$ Department of Hepatology, the First hospital of Jilin University, No.71

Xinmin Str, Changchun 130021, China

${ }^{3}$ Key Laboratory of Zoonosis Research, Ministry Education, Changchun 130021, China

Full list of author information is available at the end of the article
}

ribavirin combination therapy still plays an important role, especially in some developing countries [2].

Although HCV is a hepatotropic virus, it has also been identified in extrahepatic tissues. Numerous extrahepatic manifestations have been reported to be related to $\mathrm{HCV}$ infection, including mixed cryoglobulinemia, thyroiditis, a high prevalence of autoantibodies and metabolic disorders $[3,4]$. Recently, much attention focuses on the association between $\mathrm{HCV}$ infection and the glucose intolerance [5-7]. It was believed that $\mathrm{HCV}$ infection could induce insulin resistance (IR). Some studies showed that the prevalence of IR ranged from 30 to $70 \%$ in $\mathrm{HCV}$-infected patients regardless of the severities of liver disease, while $\mathrm{HCV}$ eradication could induce a

(c) The Author(s). 2019 Open Access This article is distributed under the terms of the Creative Commons Attribution 4.0 International License (http://creativecommons.org/licenses/by/4.0/), which permits unrestricted use, distribution, and reproduction in any medium, provided you give appropriate credit to the original author(s) and the source, provide a link to the Creative Commons license, and indicate if changes were made. The Creative Commons Public Domain Dedication waiver (http://creativecommons.org/publicdomain/zero/1.0/) applies to the data made available in this article, unless otherwise stated. 
decreased risk of insulin resistance [8-11]. However, other studies reported that there was no association between HCV clearance and metabolic syndrome [12].

In this study, we aimed to investigate the association of HCV infection with serum glucose levels, and the impact of antiviral treatment on glucose metabolism.

\section{Methods \\ Subjects}

A total of 631 Chinese Han subjects were enrolled in this study, including 306 chronic hepatitis $\mathrm{C}(\mathrm{CHC})$ patients and 325 healthy controls. All subjects were originally included in a previous epidemiological investigation of HCV infection carried out by the First Hospital of Jilin University in Fuyu county of Jilin Province from 2012 to 2014. Chronic HCV infection was defined as anti-HCV positive and detectable serum HCV RNA for more than 6 months. Patients with concomitant human immunodeficiency virus, co-infection of hepatitis B virus, liver cirrhosis or diabetes mellitus were excluded. Patients who were currently receiving or recently received anti-viral treatment were also excluded. The healthy controls satisfied the following criterion: (a) body mass index (BMI) $<30 \mathrm{~kg} / \mathrm{m}^{2}$; (b) anti-HCV was negative; (c) fasting glucose $<6.10 \mathrm{mmol} / \mathrm{l}$. The healthy controls were also matched to $\mathrm{CHC}$ by age, sex and body mass index (BMI). Subjects with any liver disease or diabetes history were excluded. Baseline data including age, gender, body mass index (BMI), serum fasting blooding glucose (FBG), aspartate transaminase (AST), alanine transaminase (ALT), alkaline phosphatase (ALP) and gamma-glutamyltransferase (GGT) were collected. BMI was calculated as weight in kilograms divided by height in square meters.

From the $306 \mathrm{CHC}$ patients, 183 patients were selected for treatment after screening for medical and mental health-related contraindications, and were offered recombinant interferon $\alpha-2 b$ (500,000 IU, 3 times/ week, Beijing Kavin Technology Share-holding Co, Ltd. China) subcutaneously, and oral ribavirin $(15 \mathrm{mg} / \mathrm{kg} /$ day $)$ over 48 weeks (for genotype 1 and 2). This antiviral combination was selected to be studied for economic reasons. Patients were monitored until 24 weeks after the end of the treatment. All of the 183 treated patients were compliant with medications taking at least $80 \%$ of the dose and in $80 \%$ of the time, and the results of this group were analyzed.

The 183 treated patients were divided into two groups according to their virological response. Sustained virological response (SVR) was defined as an undetectable HCV RNA during at least six months after completion of therapy.

The study protocol was approved by the ethics committee of the First Hospital of Jilin University. Written informed consent for all testing was obtained prior to enrollment.

\section{Laboratory investigations}

Blood samples were obtained in the morning after more than $8 \mathrm{~h}$ fasting, and measured in the Clinical Laboratory of the First Hospital of Jilin University. The tests for biochemistry, liver function, renal function, blood glucose, fasting insulin and $\mathrm{C}$ peptide were performed using a Synchron LX 20 autoanalyser (Beckman Coulter, Brea, CA, USA). HCV RNA was determined by quantitative real-time polymerase chain reaction using the COBAS AmpliPrep/COBAS TaqMan (Roche Diagnostics, Mannheim, Germany), and the lower detection limit was 15 $\mathrm{IU} / \mathrm{ml}$. Level of anti-HCV was measured using an Abbott ARCHITECT i2000SR. HCV genotype performed using multicolor fluorescence PCR with an HCV RNA genotype kit (BioAssay Science \& Technology Co. Ltd., China).

$\mathrm{HCV}$ viral load, $\mathrm{HCV}$ genotype, serum FBG, fasting insulin levels (FINS) and fasting C peptide (FCP) were collected respectively at baseline, at the end of treatment and at week 24 post-treatment. Three parameters of glucose metabolism, including homeostasis model assessment of insulin resistance (HOMA-IR), homeostasis model assessment- $\beta$ (HOMA- $\beta$ ) and insulin sensitivity index (ISI), were evaluated by the homeostasis model assessment and were calculated as follows:

HOMA-IR $=$ FINS $(\mu \mathrm{U} / \mathrm{ml}) \times$ FBG $(\mathrm{mmol} / \mathrm{l}) / 22.5$.

HOMA $-\beta=20 \times$ FINS $(\mu \mathrm{U} / \mathrm{ml}) /(\mathrm{FBG}(\mathrm{mmol} / \mathrm{l})-3.5)$.

ISI $=\ln 1 /$ FINS $(\mu \mathrm{U} / \mathrm{ml}) \times$ FBG $(\mathrm{mmol} / \mathrm{l})$.

\section{Statistical analysis}

Continuous variables were presented as means \pm SD or median (inter-quartile range), while categorical variables were expressed as frequencies (\%). Continuous variables between groups were analyzed using a Student $t$-test or Mann-Whitney $U$ test while categorical variables were analyzed using a chi-squared test. HCV RNA levels were expressed as the mean \pm standard deviation after logarithmic transformation of original values. Multivariate logistic regression was performed as appropriate. The procedures were performed using the SPSS 18.0 statistical package. All statistical analyses were based on two side hypothesis tests, with values $P<0.05$ considered to indicate statistical significance.

\section{Results}

Demographic and clinical characteristics of the HCVinfected patients and the healthy control group Demographic and clinical characteristics of the HCVinfected patients and the healthy control groups were presented in Table 1 . There was no significant difference in age, gender and BMI between two groups $(P=0.143$; 
Table 1 Baseline characteristics of chronic hepatitis C patients and controls

\begin{tabular}{llll}
\hline Characteristic & HCV & Control & $P$ value \\
\hline $\mathrm{N}$ & 306 & 325 & \\
Male (\%) & $191(62.4)$ & $179(55.1)$ & 0.129 \\
Mean age (years) & $46.34 \pm 5.42$ & $45.97 \pm 6.22$ & 0.143 \\
BMl & $23.27 \pm 3.14$ & $23.53 \pm 2.59$ & 0.247 \\
FBG $(\mathrm{mmol} / \mathrm{l})$ & $5.57 \pm 0.74$ & $5.11 \pm 0.83$ & $<0.001$ \\
ALT $(\mathrm{U} / \mathrm{L})$ & $50.4(29.8-80.35)$ & $27.4(18.7-42.65)$ & $<0.001$ \\
AST $(\mathrm{U} / \mathrm{L})$ & $38.0(27.65-62.8)$ & $24.85(19.8-33.8)$ & $<0.001$ \\
ALP $(\mathrm{U} / \mathrm{L})$ & $79.0(64.0-95.0)$ & $77.0(63.0-93.0)$ & $<0.001$ \\
GGT $(\mathrm{U} / \mathrm{L})$ & $40.0(23.0-96.0)$ & $24.5(16.0-47.45)$ & $<0.001$ \\
\hline Data & &
\end{tabular}

Data are expressed as mean $\pm S D$, median (interquartile range) or as number of patients

$B M I$ body mass index, FBG fasting blood glucose, $A L T$ alanine transaminase, AST aspartate transaminase, ALP alkaline phosphatase, GGT gamma-glutamy Itranspeptidase

$P=0.129$ and $P=0.247$, respectively). HCV-infected group had a significantly higher baseline fasting blood glucose levels than healthy control $(5.57 \pm 0.74$ vs. $5.11 \pm 0.83, P<0.001)$. AST, ALT, ALP and GGT levels were also significantly higher in HCV group $(P<0.001$ for all).

\section{Baseline characteristics of SVR and non-SVR patients}

Baseline characteristics of $183 \mathrm{HCV}$-infected patients are presented in Table 2. SVR was obtained in $59.6 \%(n=$ $109)$, and non-SVR in $40.4 \%(n=74)$ of the 183 patients. There was no significant difference in gender and BMI between the two groups. Most HCV genotypes of the patients were $1 \mathrm{~b}$ or $2 \mathrm{a}$, except 3 patients whose HCV genotypes were not determined. Significant difference was observed in age, genotype, HCV load, ALT and AST levels between SVR and non-SVR groups. The predictors of SVR were young age $(P=0.008)$, non-genotype $1(P<$ $0.001)$, low HCV load $(P<0.001)$, high ALT $(P=0.038)$ and AST levels $(P=0.033)$ with univariate analysis. However, baseline FBG, INS and HOMA-IR negatively affected treatment response $(P=0.159,0.534,0.314)$.

Multiple regression analysis found that old age $(P=$ $0.004, \mathrm{OR}=1.072,95 \% \mathrm{CI}: 1.023,1.123)$, high viral load $(P<0.001, \mathrm{OR}=2.316,95 \% \mathrm{CI}: 1.596,3.362)$ and genotype $1 \mathrm{~b}(P<0.001, \mathrm{OR}=2.016,95 \% \mathrm{CI}: 1.116,3.122)$ were predictive of a poor virological response.

\section{Changes in insulin resistance and beta-cell function after antiviral therapy in SVR and non-SVR group}

To investigate the effects of HCV clearance on glucose metabolism, we compared some of the metabolic indices of SVR and non-SVR group. Changes in insulin resistance and beta-cell function after antiviral therapy in SVR and non-SVR patients are summarized in Tables 3 and 4. In SVR group, serum FBG, FINS
Table 2 Baseline Characteristics of the Treated HCV Group

\begin{tabular}{|c|c|c|c|}
\hline & SVR & non-SVR & $P$ value \\
\hline $\mathrm{N}$ & 109 & 74 & \\
\hline Male(\%) & 79 (72.5\%) & 51 (68.9\%) & 0.622 \\
\hline Mean age (years) & $48.4 \pm 7.82$ & $51.8 \pm 7.41$ & 0.008 \\
\hline BMI & $23.7 \pm 2.72$ & $23.7 \pm 3.02$ & 0.798 \\
\hline HCV load $\left(\log _{10}\right)$ & $5.64 \pm 1.01$ & $6.35 \pm 0.76$ & $<0.001$ \\
\hline \multicolumn{4}{|l|}{ HCV genotype (\%) } \\
\hline $1 b$ & 50 (45.9\%) & 61 (82.4\%) & \multirow[t]{3}{*}{$<0.001$} \\
\hline $2 a$ & $56(51.4 \%)$ & $13(17.6 \%)$ & \\
\hline Unclassified & $3(2.7 \%)$ & - & \\
\hline FBG (mmol/l) & $5.14 \pm 0.81$ & $5.52 \pm 0.83$ & 0.159 \\
\hline FCP (nmol/l) & $0.92 \pm 0.25$ & $0.95 \pm 0.33$ & 0.409 \\
\hline FINS $(\mu \mathrm{U} / \mathrm{ml})$ & $8.30 \pm 3.80$ & $9.08 \pm 4.88$ & 0.534 \\
\hline HOMA-IR & $2.00 \pm 1.02$ & $2.27 \pm 1.37$ & 0.314 \\
\hline HOMA- $\beta$ & $104.5 \pm 71.92$ & $104.5 \pm 77.53$ & 0.9 \\
\hline$|S|$ & $-3.70 \pm 0.45$ & $-3.77 \pm 0.56$ & 0.353 \\
\hline $\mathrm{ALT}(\mathrm{U} / \mathrm{L})$ & $64.0(34.3,131.5)$ & $49.6(30.7,72.6)$ & 0.038 \\
\hline AST (U/L) & $49.4(32.2,75.5)$ & $39.9(30.5,62.6)$ & 0.033 \\
\hline ALP (U/L) & $85.0(70.5,113.5)$ & $86.0(64.8,106.5)$ & 0.642 \\
\hline GGT (U/L) & $45.0(25.3,90.8)$ & $44.0(23.3,86.3)$ & 0.731 \\
\hline $\operatorname{ALB}(g / l)$ & $48.2(44.7,52.5)$ & $46.9(43.9,50.0)$ & 0.064 \\
\hline TBIL $(\mu \mathrm{mol} / \mathrm{l})$ & $17.8(12.9,28.2)$ & $15.9(11.3,23.0)$ & 0.529 \\
\hline CHE (U/L) & $7598(6721,8030)$ & $7835(6870,8148)$ & 0.09 \\
\hline
\end{tabular}

Data are expressed as mean $\pm S D$, median (interquartile range) or as number of patients

$B M I$ body mass index, $T C$ total cholesterol, $T G$ triglyceride, $F B G$ fasting blood glucose, FCP fasting C peptide, FINS fasting insulin, HOMA-IR homeostasis model assessment for insulin resistance, HOMA- $\beta$ Homeostasis model assessment for beta-cell function, ISI insulin sensitivity index, ALT alanine transaminase, AST aspartate transaminase, ALP alkaline phosphatase, GGT gamma-glutamyltransferase, $A L B$ albumin, $T B I L$ total bilirubin, CHE cholinesterase

and FCP levels significantly decreased after the end of treatment (from $5.41 \pm 0.8$ to $4.60 \pm 0.68 \mathrm{mmol} / \mathrm{l}, P<$ 0.001 ; from $8.30 \pm 3.80$ to $7.88 \pm 4.15 \mu \mathrm{U} / \mathrm{ml}, \quad P=$ 0.007 ; from $0.92 \pm 0.25$ to $0.72 \pm 0.26 \mathrm{nmol} / \mathrm{l}, P<0.001$, respectively). HOMA-IR values also decreased at the end of treatment (from $2.00 \pm 1.02$ to $1.62 \pm 0.94, P<$ 0.001 ), and rebounded to $1.86 \pm 1.20$ at 24 weeks after treatment. Correspondingly, ISI values increased from $-3.70 \pm 0.45$ at baseline to $-3.45 \pm 0.54$ (Table 3). However, no significant changes in both parameters of glucose metabolism and HOMA-IR values were observed in non-SVR group (Table 4).

HOMA- $\beta$ values in both groups were obviously increased at the end of treatment compared with baseline $(P<0.001$ for both). The values decreased slightly at 24 week after end of treatment, but were still higher than pre-treatment levels $(P=0.01$ and $P=$ 0.08 , respectively). 
Table 3 Time course of changes in serum beta-cell function during antiviral treatment of patients with SVR

\begin{tabular}{|c|c|c|c|c|c|}
\hline & Baseline & End-Rx & FU-24 & $P^{1}$ value & $P^{2}$ value \\
\hline FBG $(\mathrm{mmol} / \mathrm{l})$ & $5.41 \pm 0.81$ & $4.60 \pm 0.68$ & $5.09 \pm 0.83$ & $<0.001$ & 0.002 \\
\hline FINS $(\mu \mathrm{U} / \mathrm{ml})$ & $8.30 \pm 3.80$ & $7.88 \pm 4.15$ & $8.18 \pm 3.99$ & 0.007 & 0.806 \\
\hline FCP $(\mathrm{nmol} / \mathrm{l})$ & $0.92 \pm 0.25$ & $0.72 \pm 0.26$ & $0.78 \pm 0.27$ & $<0.001$ & 0.000 \\
\hline HOMA-IR & $2.00 \pm 1.02$ & $1.62 \pm 0.94$ & $1.86 \pm 1.20$ & $<0.001$ & 0.052 \\
\hline HOMA- $\beta$ & $104.5 \pm 71.9$ & $183.7 \pm 127.8$ & $134.3 \pm 108.6$ & $<0.001$ & 0.01 \\
\hline$|S|$ & $-3.70 \pm 0.45$ & $-3.45 \pm 0.54$ & $-3.60 \pm 0.52$ & $<0.001$ & 0.05 \\
\hline
\end{tabular}

Data are expressed as mean \pm SD;

FBG fasting blood glucose, FINS fasting insulin, FCP fasting C peptide, HOMA-IR homeostasis model assessment for insulin resistance, HOMA- $\beta$ homeostasis model assessment for beta-cell function, ISI insulin sensitivity index, $R x$ treatment; FU-24, follow up at 24 weeks post treatment

$P^{1}$, value for comparison of baseline and end-Rx values; $P^{2}$, value for comparison of baseline and FU-24 values

\section{Discussion}

In the present study, we evaluated the association of $\mathrm{HCV}$ infection and glucose metabolism; the effect of antiviral treatment on glucose metabolism was also studied [13].

Our results showed that the level of FBG in HCV group was higher than that in control group, which was consistent with other studies. Previous studies has revealed that $\mathrm{HCV}$ infection causes insulin resistance and glucose abnormalities even type 2 diabetes mellitus (T2DM) in susceptible individuals [11, 14]. Another long period follow-up study showed the cumulative incidence of T2DM in anti-HCV positive patients reached 14.3\% while only $8.6 \%$ in seronegative individuals $(P<0.0001)$ [15].

The relation between IR and SVR are controversy. Our study revealed that many factors at baseline such as age, HCV genotype, HCV load, ALT and AST levels were able to predict SVR, but there was no significant association between FBG, INS, HOMA-IR with SVR. A meta-analysis for the association between insulin resistance and SVR in hepatitis-C infected patients indicated that there was no relation between them and the mean value of HOMA-IR was less than 3 at baseline in all studies [16]. Other studies reported that pretreatment glucose intolerance and IR could impair the therapy outcome $[17,18]$. The association of IR and SVR needs further prospective studies.
Clearance of HCV infection may improve IR and increase insulin sensitivity. In our study, we found that in SVR patients eradication of $\mathrm{HCV}$ by interferon-based therapy could improve insulin resistant and decreased fasting insulin as well as $\mathrm{C}$ peptide levels, whereas no significant difference in these indices was found in nonSVR patient. This result suggested that $\mathrm{HCV}$ itself might be involved in the development of insulin resistance. The mechanisms that $\mathrm{HCV}$ induces glucose metabolism abnormities are not very clear.

Several different mechanisms may be involved. HCVinduced liver inflammation and cirrhosis may reduce the uptake of glucose by hepatic cells, then affect the glucose metabolism [19]; HCV infection may also impair IRS-1 tyrosine phosphorylation. As anessential molecule in insulin signaling, the dysfunction of IRS-1 could decrease downstream insulin effects, thereby contributing to glucose intolerance. Clearance of $\mathrm{HCV}$ results in a significant increase of IRS-1 expression, which may partly restore glucose metabolism [7, 20]. In addition, $\mathrm{HCV}$ core proteins may functionally inhibit insulin signaling via increasing the level of tumor necrosis factoralpha (TNF- $\alpha$ ), which is an important factor mediating insulin signaling [21]. HCV core proteins also down regulate the cell surface expression of glucose transporter 2 (GLUT2), promoting hepatic gluconeogenesis via suppression of glucose uptake [19,22]. Finally, some proinflammatory cytokines such as IL- 6 and TGF- $\beta$ also

Table 4 Time course of changes in serum beta-cell function during antiviral treatment of patients non- SVR

\begin{tabular}{|c|c|c|c|c|c|}
\hline & Baseline & End-Rx & FU-24 & $P^{l}$ value & $P^{2}$ value \\
\hline FBG $(\mathrm{mmol} / \mathrm{l})$ & $5.52 \pm 0.83$ & $4.93 \pm 0.93$ & $5.23 \pm 0.74$ & $<0.001$ & 0.023 \\
\hline FINS $(\mu \mathrm{U} / \mathrm{ml})$ & $9.08 \pm 4.88$ & $9.05 \pm 5.07$ & $9.58 \pm 5.12$ & 0.546 & 0.888 \\
\hline FCP $(\mathrm{nmol} / \mathrm{l})$ & $0.95 \pm 0.33$ & $0.97 \pm 0.29$ & $0.93 \pm 0.31$ & 0.609 & 0.819 \\
\hline HOMA-IR & $2.27 \pm 1.37$ & $2.16 \pm 1.42$ & $2.49 \pm 1.37$ & 0.281 & 0.195 \\
\hline HOMA- $\beta$ & $104.5 \pm 77.5$ & $178.7 \pm 148.3$ & $144.3 \pm 102.9$ & $<0.001$ & 0.08 \\
\hline$|S|$ & $-3.77 \pm 0.56$ & $-3.69 \pm 0.63$ & $-3.87 \pm 0.59$ & 0.250 & 0.264 \\
\hline
\end{tabular}

Data are expressed as mean $\pm \mathrm{SD}$

FBG fasting blood glucose, FINS fasting insulin, FCP fasting C peptide, HOMA-IR homeostasis model assessment for insulin resistance, HOMA- $\beta$ homeostasis model assessment for beta-cell function, ISI insulin sensitivity index, $R x$ treatment; FU-24, follow up at week 24 post treatment

$P^{1}$, value for comparison of baseline and end-Rx values; $P^{2}$, value for comparison of baseline and FU-24 values 
have been identified to be able to reduce glucose uptake and impair glucagon metabolism in $\mathrm{HCV}$ infected patients.

Our study also showed that HOMA- $\beta$ was significantly increased after antiviral treatment regardless of the outcome. The mechanism may be attribute to the restoration of insulin sensitivity after the clearance of $\mathrm{HCV}$ [23]. The current data confirmed that HOMA- $\beta$ values increased in the $\mathrm{CHC}$ patients as compensation for insulin resistance $[24,25]$, and at the same time the status of beta-cell hyperfunction was ameliorated after successful treatment [26]. The mechanisms that whether or not $\mathrm{HCV}$ could change the function of beta-cell in chronic hepatitis $\mathrm{C}$ patients remains unclear. Early studies reported that virus-like particles were detected in the pancreatic beta cells of $\mathrm{HCV}$ patients, which could induce death of pancreatic beta cells through multiple mechanisms $[27,28]$. While many clinical studies reported that beta-cell function was preserved [29].

Larger amount of samples was included in our study than other studies $[2,14]$, which increased the statistical reliability of the results. Although the therapy agents in the study were no longer generally used for the treatment of $\mathrm{HCV}$, the interferon and ribavirin combination therapy still plays an important role in certain limited resource settings. There were also certain limitations. The current study was retrospective, and some data missed in some cases. However, we proposed that no matter what kind of antiviral treatment was used, clearance of HCV could improve insulin resistant and decrease fasting glucose $[11,20]$. It is still interesting to study the impact of conventional methods on metabolic endpoints.

\section{Conclusions}

The current study showed that chronic HCV-infected patients had higher fasting blood glucose levels than healthy controls. Successful clearance of $\mathrm{HCV}$ by interferon-based therapy led to reversal of hyperglycemia and improvement of insulin resistance However, the effect of HCV infection on beta cell function is complex and further studies are required to clarify their association.

\section{Abbreviations \\ ALP: Alkaline phosphatase; ALT: Alanine transaminase; AST: Aspartate transaminase; BMI: Body mass index; CHC: Chronic hepatitis C; FBG: Fasting blood glucose; FCP : Fasting C peptide; FINS: fasting insulin levels; GGT: Gamma- glutamyltransferase; HCV: Hepatitis C virus; HOMA- IR: Homeostasis model assessment of insulin resistance; HOMA- $\beta$ : Homeostasis model assessment- $\beta$; ISI: Insulin sensitivity index; SVR: Sustained virological response}

\section{Acknowledgements}

The authors want to claim that the work has been presented as a poster presentation at 66th American Association for the Study of Liver Diseases (AASLD), San Francisco, USA, 2015.

\section{Authors' contributions}

All contributing authors have agreed to the submission of this manuscript for publication. $\mathrm{YL}, \mathrm{XW}$ and $\mathrm{JN}$ designed and were major contributors in writing the manuscript. GY, HS, and JL acquired data. XC, RW and XG performed the examination of the FBG and other tests. All authors have read and approved the final version of this manuscript.

\section{Funding}

The study was sponsored by the National Basic Research Program of China (973 Program) (2015CB554300), the National Natural Science Foundation of China (grants No.81301472).

\section{Availability of data and materials}

The datasets used and analyzed during the current study are available from the corresponding author on reasonable request.

Ethics approval and consent to participate

The study protocol was approved by the ethics committee of the First Hospital of Jilin University. Written informed consent for all testing was obtained prior to enrollment.

\section{Consent for publication}

Not applicable. No details, images, or videos relating to individual participants are included in the manuscript.

\section{Competing interests}

All authors declare no conflict of interest.

\section{Author details}

'Department of Hepatology, the First hospital of Jilin University, No.71 Xinmin Str, Changchun 130021, China. ${ }^{2}$ Department of Gastroenterology, Shouguang City People's Hospital, Shouguang 262700, China. ${ }^{3}$ Key Laboratory of Zoonosis Research, Ministry Education, Changchun 130021, China.

Received: 21 June 2017 Accepted: 29 May 2019

Published online: 13 June 2019

\section{References}

1. Lauer GM, Walker BD. Hepatitis C virus infection. N Engl J Med. 2001;345(1): $41-52$.

2. Qing S, Ji D, Li B, Li F, Wang Y, Niu X, Ling B, Meng Y, Lau G, Chen G. Improvement of glucose and lipid metabolism with pegylated interferon-a plus ribavirin therapy in Chinese patients chronically infected with genotype 1b hepatitis C virus. Ann Saudi Med. 2015;35(4):293-7.

3. Cacoub P, Renou C, Rosenthal E, Cohen P, Loury I, Loustaud-Ratti V, Yamamoto AM, Camproux AC, Hausfater P, Musset L, et al. Extrahepatic manifestations associated with hepatitis $C$ virus infection. A prospective multicenter study of 321 patients. The GERMIVIC. Groupe d'Etude et de Recherche en Medecine interne et maladies Infectieuses Sur le virus de I'Hepatite C. Medicine (Baltimore). 2000;79(1):47-56.

4. Cacoub P, Gragnani L, Comarmond C, Zignego AL. Extrahepatic manifestations of chronic hepatitis C virus infection. Dig Liver Dis. 2014; 46(Suppl 5):S165-73.

5. Narita R, Abe S, Kihara Y, Akiyama T, Tabaru A, Otsuki M. Insulin resistance and insulin secretion in chronic hepatitis C virus infection. J Hepatol. 2004; 41(1):132-8

6. Moucari R, Asselah T, Cazals-Hatem D, Voitot H, Boyer N, Ripault MP, Sobesky R, Martinot-Peignoux M, Maylin S, Nicolas-Chanoine MH, et al. Insulin resistance in chronic hepatitis C: association with genotypes 1 and 4, serum HCV RNA level, and liver fibrosis. Gastroenterology. 2008; 134(2):416-23.

7. Aytug S, Reich D, Sapiro LE, Bernstein D, Begum N. Impaired IRS-1/PI3-kinase signaling in patients with HCV: a mechanism for increased prevalence of type 2 diabetes. Hepatology. 2003;38(6):1384-92.

8. Taskoparan M, Serin E, Gokturk HS, Icer MO, Abaci K, Ozer B, Zumrutdal A, Yilmaz $U$. Early effect of peginterferon alpha-2b plus ribavirin treatment on blood pressure and insulin resistance in patients with chronic hepatitis C. Hepatogastroenterology. 2011;58(107-108):875-9.

9. Tada S, Saito H, Ebinuma H, Ojiro K, Yamagishi Y, Kumagai N, Inagaki Y, Masuda T, Nishida J, Takahashi M, et al. Treatment of hepatitis $C$ virus with 
peg-interferon and ribavirin combination therapy significantly affects lipid metabolism. Hepatol Res. 2009;39(2):195-9.

10. Serfaty L, Andreani T, Giral P, Carbonell N, Chazouilleres O, Poupon R. Hepatitis C virus induced hypobetalipoproteinemia: a possible mechanism for steatosis in chronic hepatitis C. J Hepatol. 2001;34(3):428-34.

11. Adinolfi LE, Nevola R, Guerrera B, D'Alterio G, Marrone A, Giordano M, Rinaldi L. Hepatitis $C$ virus clearance by direct-acting antiviral treatments and impact on insulin resistance in chronic hepatitis $C$ patients. J Gastroenterol Hepatol. 2018;33(7):1379-82.

12. Cheng YL, Wang YC, Lan KH, Huo Tl, Huang YH, Su CW, Lin HC, Lee FY, Wu JC, Lee SD. Anti-hepatitis C virus seropositivity is not associated with metabolic syndrome irrespective of age, gender and fibrosis. Ann Hepatol. 2015;14(2):181-9.

13. Yinping Li XW, Hongqin X, Ruihong W, Chi X, Gao X, Pan Y, Niu J. The influence of hepatitis $C$ virus infection and its clearance on the serum lipid profile and glucose leve. American Association for the Study of Liver Diseases (AASLD). 2015.

14. Yair-Sabag S, Nussinson E, Ben-Assuli O, Shibli F, Shahbari A, Zelber-Sagi S. Retrospective study of the associations between hepatitis $C$ virus infection and metabolic factors. World J Hepatol. 2016;8(30):1269-78.

15. Wang CS, Wang ST, Yao WJ, Chang TT, Chou P. Hepatitis C virus infection and the development of type 2 diabetes in a community-based longitudinal study. Am J Epidemiol. 2007:166(2):196-203.

16. Eslam M, Aparcero R, Kawaguchi T, Del Campo JA, Sata M, Khattab MA, Romero-Gomez M. Meta-analysis: insulin resistance and sustained virological response in hepatitis C. Aliment Pharmacol Ther. 2011;34(3):297-305.

17. Romero-Gomez M, Del Mar Viloria M, Andrade RJ, Salmeron J, Diago M, Fernandez-Rodriguez CM, Corpas R, Cruz M, Grande L, Vazquez L, et al. Insulin resistance impairs sustained response rate to peginterferon plus ribavirin in chronic hepatitis C patients. Gastroenterology. 2005;128(3):636-41.

18. Poustchi H, Negro F, Hui J, Cua IH, Brandt LR, Kench JG, George J. Insulin resistance and response to therapy in patients infected with chronic hepatitis C virus genotypes 2 and 3. J Hepatol. 2008;48(1):28-34

19. Kralj D, Virovic Jukic L, Stojsavljevic S, Duvnjak M, Smolic M, Curcic IB. Hepatitis C virus, insulin resistance, and steatosis. J Clin Transl Hepatol. 2016;4(1):66-75.

20. Kawaguchi T, Ide T, Taniguchi E, Hirano E, Itou M, Sumie S, Nagao $Y$, Yanagimoto C, Hanada S, Koga H, et al. Clearance of HCV improves insulin resistance, beta-cell function, and hepatic expression of insulin receptor substrate 1 and 2. Am J Gastroenterol. 2007;102(3):570-6.

21. Knobler H, Zhornicky T, Sandler A, Haran N, Ashur Y, Schattner A. Tumor necrosis factor-alpha-induced insulin resistance may mediate the hepatitis $C$ virus-diabetes association. Am J Gastroenterol. 2003;98(12):2751-6.

22. Shoji I, Deng L, Matsui C, Hotta H. Hepatitis C virus-induced glucose metabolic disorder. Uirusu. 2015;65(2):263-8.

23. Carvalho JR, Velosa J, Serejo F. Lipids, glucose and iron metabolic alterations in chronic hepatitis $C$ after viral eradication - comparison of the new direct-acting antiviral agents with the old regimens. Scand J Gastroenterol. 2018:1-7.

24. Kawaguchi Y, Mizuta T, Oza N, Takahashi H, Ario K, Yoshimura T, Eguchi Y, Ozaki I, Hisatomi A, Fujimoto K. Eradication of hepatitis C virus by interferon improves whole-body insulin resistance and hyperinsulinaemia in patients with chronic hepatitis C. Liver Int. 2009:29(6):871-7.

25. Furutani M, Nakashima T, Sumida Y, Hirohama A, Yoh T, Kakisaka Y, Mitsuyoshi H, Senmaru H, Okanoue T. Insulin resistance/beta-cell function and serum ferritin level in non-diabetic patients with hepatitis $C$ virus infection. Liver Int. 2003;23(4):294-9.

26. Huang JF, Dai CY, Yu ML, Huang CF, Huang Cl, Yeh ML, Yang JF, Hou NJ, Hsiao PJ, Lin ZY, et al. Pegylated interferon plus ribavirin therapy improves pancreatic beta-cell function in chronic hepatitis C patients. Liver Int. 2011; 31(8):1155-62

27. Wang $Q$ Chen J, Wang $Y$, Han $X$, Chen $X$. Hepatitis $C$ virus induced a novel apoptosis-like death of pancreatic beta cells through a caspase 3dependent pathway. PLoS One. 2012;7(6):e38522.

28. Masini M, Campani D, Boggi U, Menicagli M, Funel N, Pollera M, Lupi R, Del Guerra S, Bugliani M, Torri S, et al. Hepatitis C virus infection and human pancreatic beta-cell dysfunction. Diabetes Care. 2005;28(4):940-1.

29. Lecube A, Hernandez C, Genesca J, Simo R. Proinflammatory cytokines, insulin resistance, and insulin secretion in chronic hepatitis $C$ patients: a case-control study. Diabetes Care. 2006;29(5):1096-101.

\section{Publisher's Note}

Springer Nature remains neutral with regard to jurisdictional claims in published maps and institutional affiliations.

\section{Ready to submit your research? Choose BMC and benefit from}

- fast, convenient online submission

- thorough peer review by experienced researchers in your field

- rapid publication on acceptance

- support for research data, including large and complex data types

- gold Open Access which fosters wider collaboration and increased citations

- maximum visibility for your research: over $100 \mathrm{M}$ website views per year

At $\mathrm{BMC}$, research is always in progress.

Learn more biomedcentral.com/submissions 